\title{
Antimicrobial activity of traditional medicinal plants from Ankober District, North Shewa Zone, Amhara Region, Ethiopia
}

\author{
E. Lulekal ${ }^{1,2}$, J. Rondevaldova ${ }^{3}$, E. Bernaskova ${ }^{3}$, J. Cepkova ${ }^{3}$, Z. Asfaw ${ }^{2}$, E. Kelbessa ${ }^{2}$, L. Kokoska ${ }^{3}$, and \\ P. Van Damme ${ }^{1,3}$
}

\begin{abstract}
${ }^{1}$ Laboratory for Tropical and Subtropical Agriculture and Ethnobotany, Department of Plant Production, Faculty of Bio-Science Engineering, Ghent University, Gent, Belgium, ${ }^{2}$ Department of Plant Biology and Biodiversity Management, College of Natural sciences, Addis Ababa University, Addis Ababa, Ethiopia, and ${ }^{3}$ Department of Crop Science and Agroforestry, Institute of Tropics and Subtropics, Czech University of Life Sciences Prague, Prague, Czech Republic
\end{abstract}

\section{Abstract}

Context: Traditional medicinal plants have long been used in Ethiopia to treat human and livestock ailments. Despite a well-documented rich tradition of medicinal plant use in the country, their direct antimicrobial effects are still poorly known.

Objective: To investigate the antimicrobial activity of 19 medicinal plant species that were selected based on the ethnobotanical information on their traditional use to treat infectious diseases in Ankober District.

Methods: About 23 different ethanol extracts of plants obtained by maceration of various parts of 19 medicinal plant species were studied for potential antimicrobial activity using a broth microdilution method against Bacillus cereus, Bacteroides fragilis, Candida albicans, Clostridium perfringens, Enterococcus faecalis, Escherichia coli, Listeria monocytogenes, Pseudomonas aeruginosa, Salmonella enteritidis, Staphylococcus aureus, Staphylococcus epidermidis, and Streptococcus pyogenes.

Results: Plant extracts from Embelia schimperi Vatke (Myrsinaceae) showed the strongest antibacterial activity with a minimum inhibitory concentration (MIC) value of $64 \mu \mathrm{g} / \mathrm{ml}$ against B. cereus, L. monocytogenes, and S. pyogenes. Growth inhibitory activities were also observed for extracts of Ocimum lamiifolium Hochst. (Lamiaceae) against S. pyogenes, and those of Rubus steudneri Schweinf. (Rosaceae) against S. epidermidis at an MIC value of $128 \mu \mathrm{g} / \mathrm{ml}$. Generally, $74 \%$ of ethanol extracts (17 extracts) showed antimicrobial activity against one or more of the microbial strains tested at an MIC value of $512 \mu \mathrm{g} / \mathrm{ml}$ or below.

Discussion and conclusions: Results confirm the antimicrobial role of traditional medicinal plants of Ankober and warrant further investigations on promising medicinal plant species so as to isolate and characterise chemicals responsible for the observed strong antimicrobial activities.
\end{abstract}

\section{Keywords}

Activity testing, ethnomedicine, plant extracts

\section{History}

Received 27 June 2013

Revised 8 October 2013

Accepted 19 October 2013

Published online 27 December 2013

\section{Introduction}

Microbial diseases continued to be major threats to the world regardless of efforts and progress in developing modern medicine (Cos et al., 2006). The impact of microbial diseases is especially important in developing countries such as Ethiopia where there is limited access to modern drugs and prices are mostly unaffordable when the latter are available. Currently, the ever-increasing threat from drug-resistant bacteria calls for a global effort to search for novel solutions (Theuretzbacher, 2012) that can also be based on the natural products from plants that are selected on the basis of documented ethnomedicinal use (Verpoorte et al., 2005). A focused phytochemical screening, backed by ethnomedicinal

Correspondence: Ermias Lulekal, Laboratory for Tropical and Subtropical Agriculture and Ethnobotany, Department of Plant Production, Faculty of Bio-Science Engineering, Ghent University, Coupure Links 653, 9000 Gent, Belgium. Tel: +32 4888488583. E-mail: Ermiasmulekal.molla@Ugent.be data, often leads to the discovery of new lead compounds that can play a role in the global efforts against pathogens (Savithramma et al., 2012).

According to WHO (2008), $80 \%$ of the population in developing countries depend on herbal medicine for primary health care. The situation is the same in Ethiopia where traditional medicine has been in use since time immemorial and found to be culturally entrenched in all communities (Kibebew, 2001). About 95\% of traditional medicine preparations in the country are of plant origin (Demissew \& Dagne, 2001) as evidenced by the wealth of indigenous knowledge on the utilisation of medicinal plants for treating human and livestock ailments.

This knowledge has been recorded in ancient medicoreligious textbooks dating back to the Axumite Kingdom (7th-11th C) (Kibebew, 2001). Other documents on Ethiopian medicinal plants by foreign travelers including Cecchi (1886), Griaule (1928), Pearce (1831), Mérab (1912), Ganora (1929), and Strelcyn $(1968,1973)$ complemented the latter 
information. However, the efforts on antimicrobial screening of the country's medicinal flora remained minimal. Although there are a number of recent ethnobotanical documents on medicinal plants traditionally used in Ethiopia for the treatment of infectious diseases, such as those in Flatie et al. (2009), Giday et al. (2009, 2010), Lulekal et al. (2008), Mesfin et al. (2009), Sori et al. (2004), Teklehaymanot (2009), Teklehaymanot and Giday (2007), Wabe et al. (2011), Wondimu et al. (2007), and Yineger et al. (2007), only a few species have been tested up to now for their antibacterial or antifungal properties (Belay, 2011; Desta, 1993; GebreMariam et al., 2006; Geyid et al., 2005; Tadeg et al., 2005; Tadesse et al., 2009; Taye et al., 2011; Yonathan et al., 2006) and this is found to be insignificant when compared to the wealth of Ethiopian ethnomedicinal plants and associated knowledge.

The present study reports the results of in vitro antimicrobial tests performed on 23 ethanol extracts of various parts of 19 different plant species, which are traditionally used for treating various ailments in the study area, against 12 various strains of microbes so as to show the antimicrobial efficacy of locally reported medicinal plants.

\section{Materials and methods}

\section{Plant material}

Plant specimens were collected from Ankober District $(172 \mathrm{~km}$ northeast of the capital Addis Ababa), North Shewa Zone, Amhara Region Ethiopia, between 25 June and 26 September 2009, 9 January-20 February 2010, 22 May-27 August 2010 and 14 Febraury-7 May 2011. Identification of specimens was performed both in the field and at the National Herbarium of Ethiopia (ETH) by Ermias Lulekal and Melaku Wondafrash, which was then confirmed by Prof. Ensermu Kelbessa, using taxonomic keys and floras (Edwards et al., 2000; Hedberg \& Edwards, 1989; Hedberg et al., 2003) and by comparison with voucher reference herbarium specimens. Plant species were selected for screening based on local use reports from the study area and for which there are related ethnobotanical reports from other parts of the country (Table 1). The identified voucher specimens were deposited at the National Herbarium (ETH).

\section{Preparation of extracts}

About $15 \mathrm{~g}$ of air-dried plant material of each species was finely ground using a Grindomix apparatus (GM100 Retsch, Haan, Germany) and extracted at room temperature in $80 \%$ ethanol using a laboratory shaker for $24 \mathrm{~h}$. Extracts from each specimen were subsequently filtered and concentrated to dryness using a rotary evaporator R-200 (Buchi, Switzerland) in vacuo at $40^{\circ} \mathrm{C}$. Dry residues were then dissolved in $100 \%$ dimethyl sulfoxide (DMSO) to create a concentration of $51.2 \mathrm{mg} / \mathrm{ml}$ stock solution of each extract that was stored at $-20^{\circ} \mathrm{C}$ until tested. Yield (\%) of dry residues of each extract used is shown in Table 1.

\section{Microorganisms}

Antimicrobial activity was evaluated against one yeast and 11 bacterial strains obtained from the American Type Culture
Collection (ATCC) (Oxoid, Basingstoke, United Kingdom) and the German Resource Centre for Biological Material (DSM) (Braunschweig, Germany). Bacterial strains were selected as a representative of both classes of Gram-positive and Gram-negative bacteria. Microbial strains used were Bacillus cereus ATCC 11778, Bacteroides fragilis ATCC 25285, Candida albicans ATCC 10231, Clostridium perfringens DSM 11778, Escherichia coli ATCC 25922, Enterococcus faecalis ATCC 29212, Listeria monocytogenes ATCC 7644, Pseudomonas aeruguinosa ATCC 27853, Staphylococcus aureus ATCC 29213, Staphylococcus epidermidis ATCC 12228, Salmonella enteritidis ATCC 13076, and Streptococcus pyogenes ATCC 19615.

Streptococcus pyogenes was grown in brain-heart infusion broth (Oxoid, Basingstoke, United Kingdom). Bacteroides fragilis and $C$. perfringens as representatives of anaerobic bacteria were grown in the Wilkins-Chalgren anaerobic broth (Oxoid) under anaerobic conditions using an anaerobic jar HP11 (Oxoid). Anaerobiosis was achieved in a Bugbox anaerobic chamber (BioTrace, Bridgend, United Kingdom). Other microorganisms were all grown Mueller-Hinton broth (Oxoid), which was enriched with glucose for E. faecalis cultivation. All cultivation media were obtained from Oxoid.

The sensitivity of tested aerobic bacteria and B. fragilis to a standard antibiotic ciprofloxacin (Sigma-Aldrich, Prague, Czech Republic) was checked. For $C$. albicans and $C$. perfringens, tioconazole and penicillin $\mathrm{G}$ (both obtained from Sigma-Aldrich) were used as positive controls, respectively.

\section{Antimicrobial assay}

In vitro antimicrobial activity was determined by the broth microdilution method (Jorgensen et al., 1999) using 96-well microtiter plates modified according to the recommendations recently proposed for the more effective assessment of antiinfective potential of natural products by Cos et al. (2006). Ten two-fold serial dilutions of each extract were prepared in the appropriate broth concentrations ranging from 512 to $4 \mu \mathrm{g} / \mathrm{ml}$. Each well was then inoculated with $5 \mu \mathrm{l}$ of bacterial suspension at a density of $10^{7} \mathrm{CFU} / \mathrm{ml}$ whereas microtiter plates were incubated at $37^{\circ} \mathrm{C}$ for $24 \mathrm{~h}$ (or $48 \mathrm{~h}$ for C. albicans, B. Fragilis, and C. perfringens). All plates were then checked for minimum inhibitory concentrations (MICs).

Growth of microorganisms was observed as turbiditydetermined spectrophotometrically using the Multiscan Ascent Microplate Reader (Thermo Fisher Scientific, Waltham, MA) at $405 \mathrm{~nm}$. MICs were then calculated based on the density of the growth control and expressed as the lowest extract concentrations that resulted in $\geq 80 \%$ reduction in bacterial growth compared to that of the extract-free growth control. Tests were assayed in triplicate in three independent experiments.

\section{Results}

Among 23 plant extracts tested for antimicrobial activity, about $74 \%$ (17 extracts) showed activity at the concentration of $512 \mu \mathrm{g} / \mathrm{ml}$ or below against one or more of the 12 microbes (Table 2). Extracts of E. schimperi, O. lamiifolium, and $R$. steudneri showed the broadest spectrum of action as they 


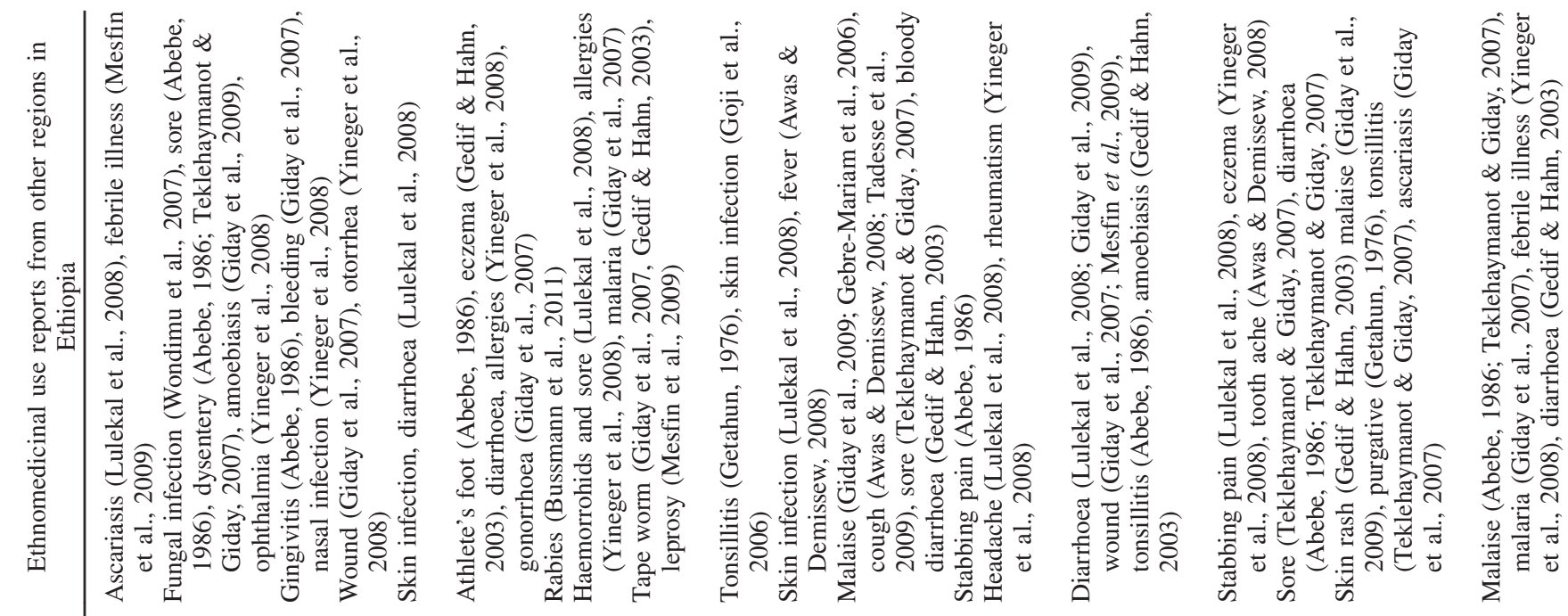

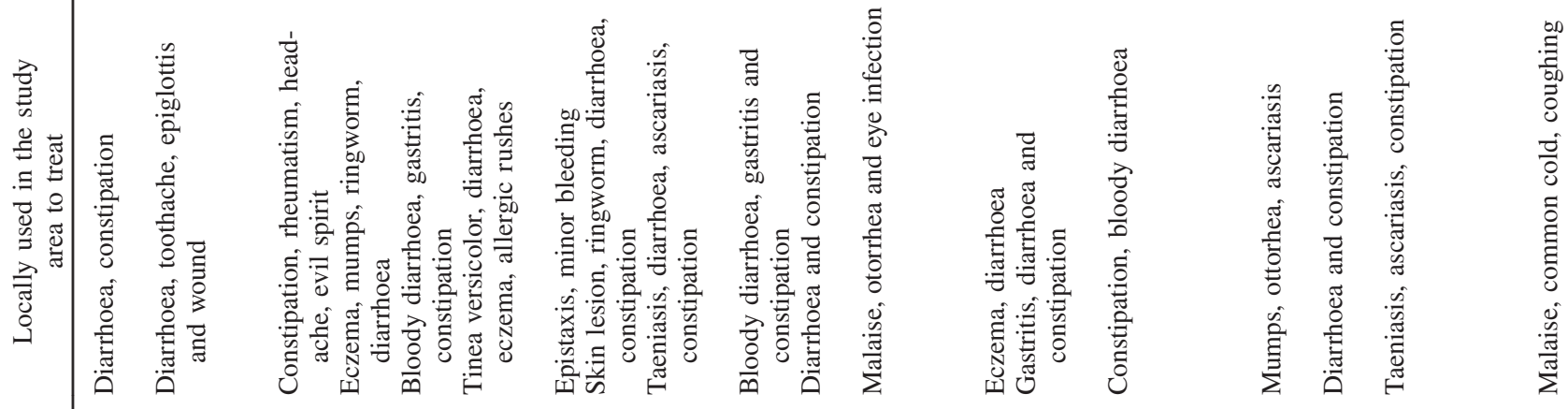

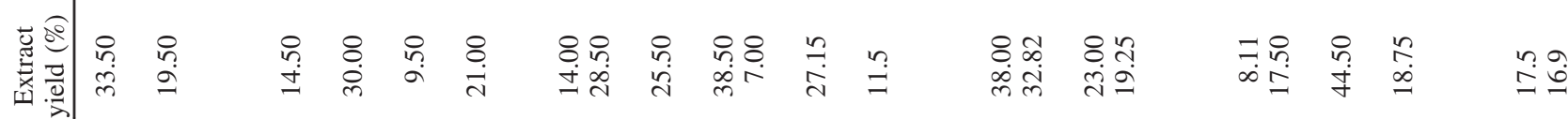

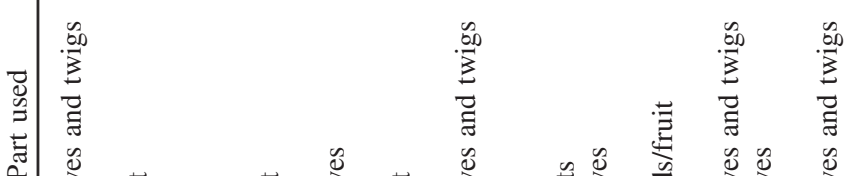

है

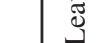

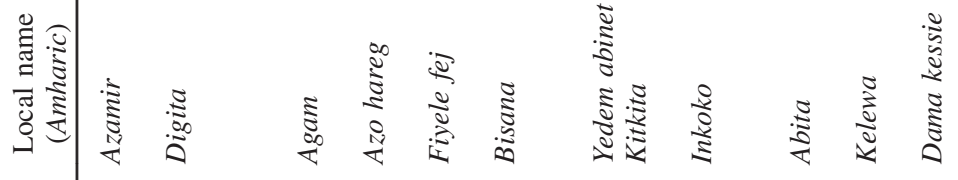<smiles>[AlH][AlH]</smiles>

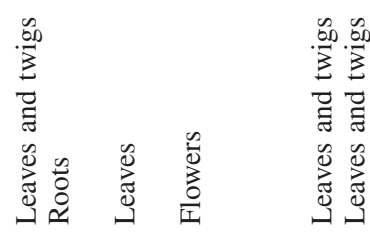

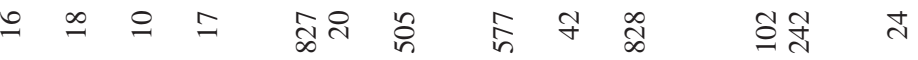

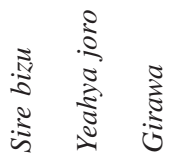

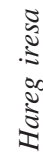
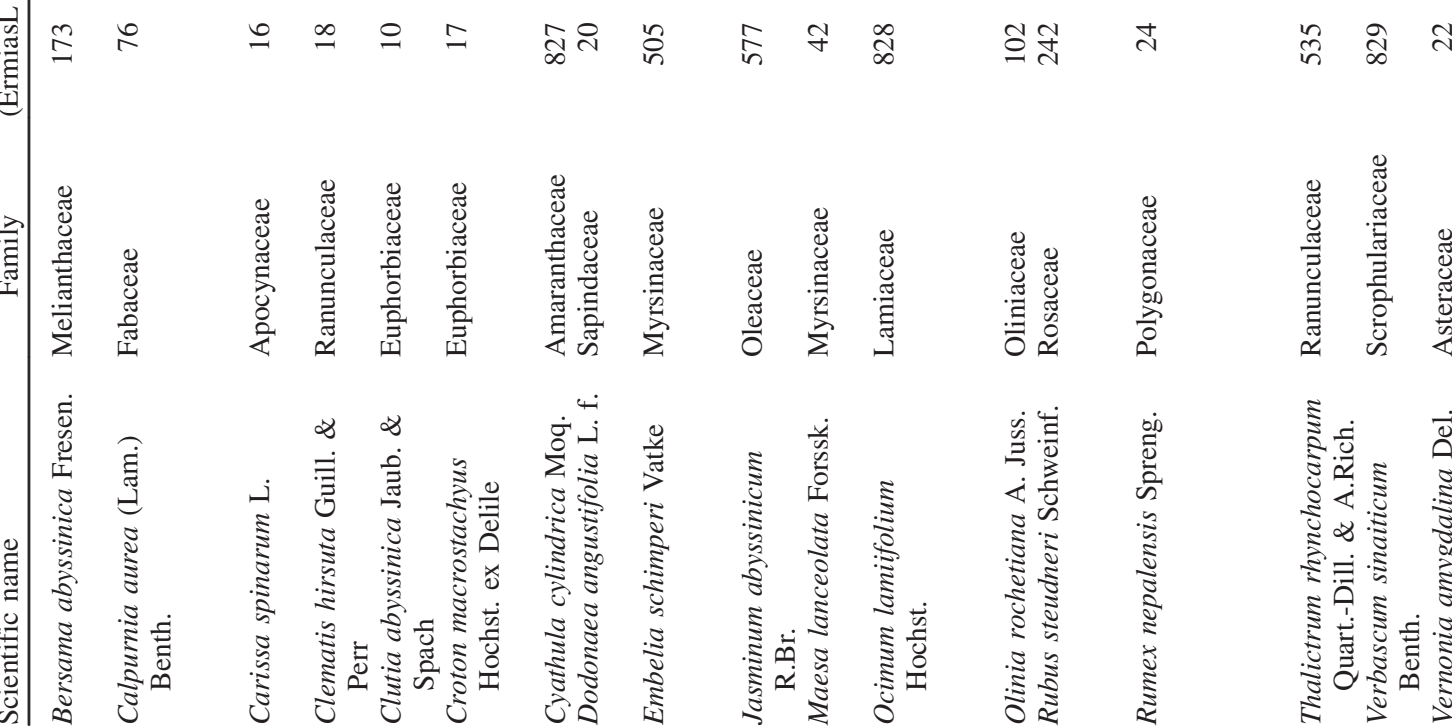
Table 2. MIC values of ethanol extracts of medicinal plant species with antimicrobial activities, Ankober District, Ethiopia.

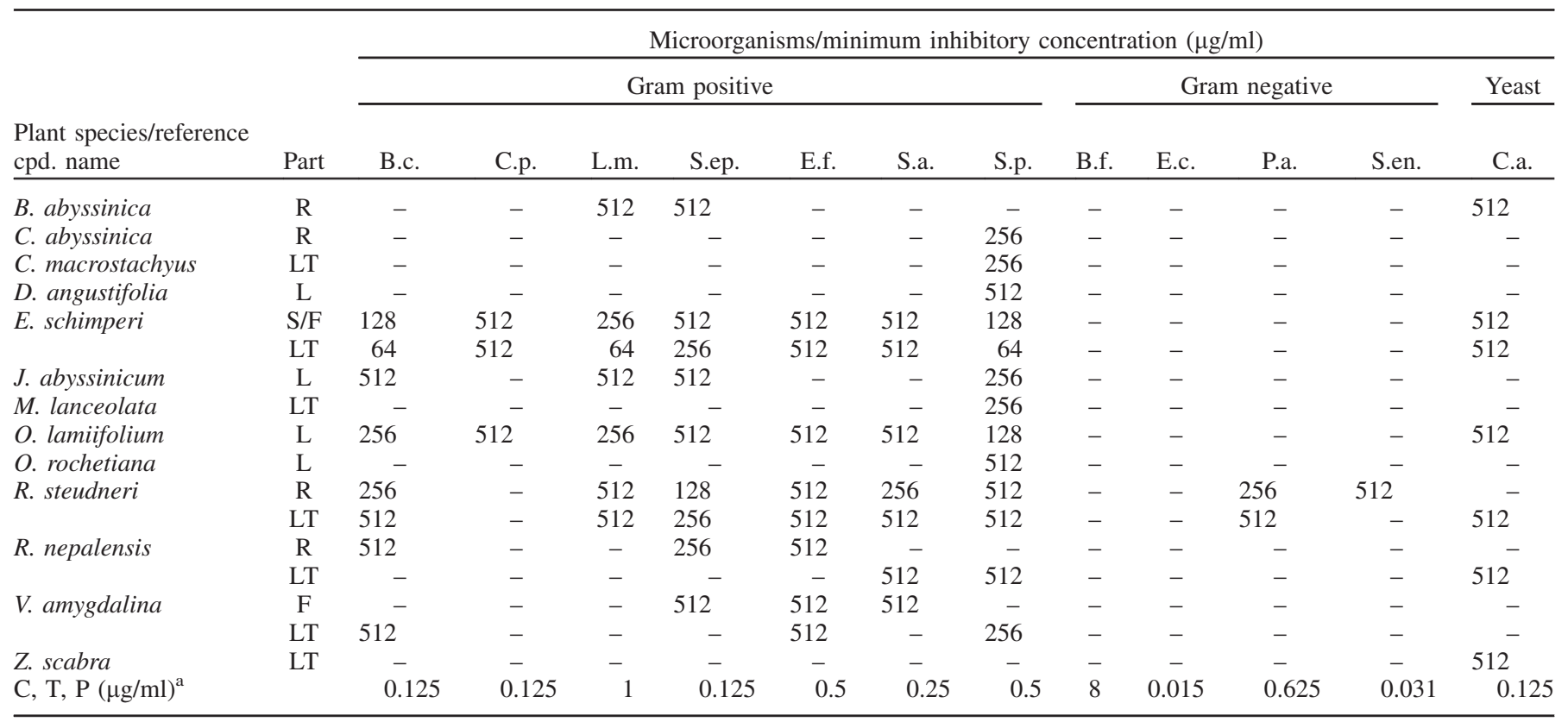

R, root; LT, leaves and twigs; S, seed; F, fruit; L, leaves; B.c., Bacillus cereus; C.p., Clostridium perfringens; L.m. Listeria monocytogenes; S.ep., Staphylococcus epidermidis; E.f., Enterococcus faecalis; S.a., Staphylococcus aureus; S.p., Streptococcus pyogenes; B.f., Bacteroides fragilis; E.c., Escherichia coli; P.a., Pseudomonas aeruguinosa; S.en., Salmonella enteritidis; C.a., Candida albicans; -, not active (>512 $\mu \mathrm{g} / \mathrm{ml})$.

${ }^{\mathrm{a}} \mathrm{C}$, ciprofloxacin; T, tioconazole; $\mathrm{P}$, penicillin.

inhibited growth of B. cereus, C. albicans, E. faecalis, $L$. monocytogenes, S. aureus, S. epidermidis, and S. pyogenes strains with MICs ranging from 64 to $512 \mu \mathrm{g} / \mathrm{ml}$. In addition, extracts of E. schimperi and $O$. lamiifolium showed inhibitory activity against $C$. perfringens at an MIC value of $512 \mu \mathrm{g} / \mathrm{ml}$, whereas those of $R$. steudneri were found effective against $P$. aeruguinosa and $S$. enteritidis in an MIC range of 256$512 \mu \mathrm{g} / \mathrm{ml}$. Moreover, extracts from J. abyssinicum, $B$. abyssinica, $R$. nepalensis, and $V$. amygdalina inhibited growth of three or more of the 12 microbes. No antimicrobial activity was observed with extracts of $C$. aurea, $C$. spinarum, C. hirsuta, C. cylindrica, T. rhynchocarpum, and V. sinaiticum against either one of the microbes tested.

The strongest antibacterial activity (MIC $=64 \mu \mathrm{g} / \mathrm{ml}$ ) was shown by leaf and twig extracts of E. schimperi against B. cereus, L. monocytogenes, and S. pyogenes. Moreover, seed and fruit extracts of this species also showed strong activity (MIC $=128 \mu \mathrm{g} / \mathrm{ml}$ ) against $B$. cereus and $S$. pyogenes. Similarly, strong growth inhibitory activities $(\mathrm{MIC}=128 \mu \mathrm{g} /$ $\mathrm{ml}$ ) were observed for extracts of $O$. lamiifolium against $S$. pyogenes, and those of $R$. steudneri against $S$. epidermidis.

Extracts of $R$. steudneri were the only extracts to show antimicrobial activity against Gram-negative bacteria $P$. aeruguinosa and $S$. enteritidis. Two of the Gram-negative bacteria, i.e., B. fragilis and E. coli, were resistant to all extracts tested in this study. Among the Gram-positive bacteria, $C$. perfringens was found to be less sensitive as inhibited by the extracts of only two species, E. schimperi and $O$. lamiifolium. S. pyogenes was shown to be the most sensitive bacterium which was inhibited by $76 \%$ of extracts (13 extracts) with MIC values ranging from 64 to $512 \mu \mathrm{g} / \mathrm{ml}$. Gram-positive bacteria were generally found more susceptible to the extracts than the Gram-negative ones. The growth of yeast strain $C$. albicans was inhibited by extracts from $B$. abyssinica, E. schimperi, O. lamifolium, R. steudneri, $R$. nepalensis, and Z. scabra. No growth inhibition was observed in the negative controls.

\section{Discussion}

The output of the present investigation substantiates the potential therapeutic role of traditionally used medicinal plants against some microbial diseases. About 17 (74\%) of the 23 ethanol extracts obtained from 19 medicinal plant species have now been proven to show antimicrobial activity against one or more of the 12 microbial strains. Results also confirm the importance of considering ethnomedicinal background of medicinal plants to run antimicrobial activity tests for a high hit-rate (74\% in this case). Similar investigations on antimicrobial activity tests based on ethnomedicinal background (Buwa \& van Staden, 2006; Eguale et al., 2007; Gebre-Mariam et al., 2006; Geyid et al., 2005; Hussain et al., 2010; Kloucek et al., 2005; Tadesse et al., 2009; Tekwu et al., 2012) have also been reported for a high hit-rate in different countries.

The broad spectrum antimicrobial activity of extracts from E. schimperi, O. lamiifolium, and $R$. steudneri, each inhibiting growth of $67 \%$ (eight) of the 12 microbes (Table 2) with a MIC range between 64 and $512 \mu \mathrm{g} / \mathrm{ml}$ supports wide traditional use reports of these species in Ethiopia and neighbouring countries (Gedif \& Hahn, 2003; Kokwaro, 1976; Mesfin et al., 2009; Pascaline et al., 2011; Teklehaymanot \& Giday, 2007; Wondimu et al., 2007). In addition, Awino et al. (2008) have reported antimicrobial activity of extracts from $E$. schimperi against $S$. aureus, which complements results of the present work. A report from the same authors on antimicrobial activity of a pure compound, 2,5-dihydroxy-3-methyl-1,4-benzoquinone, from E. schimperi 
against two of the Gram-negative bacteria i.e., P. aeruginosa and E. coli, which were shown not to be susceptible in the present work, suggests the presence of other antibacterial constituents in the extract tested in this study. Moreover, Bøgh et al. (1996) described anthelminthic usage of extracts from $E$. schimperi berries against Taenia saginata, which confirms diverse medicinal role of the species in the treatment of infective agents.

Observed strong antibacterial activity of E. schimperi against $B$. cereus, $L$. monocytogenes, and $S$. pyogenes correlates with its reported traditional use of treating diarrhoea which is one of the major bacterial diseases in the study area. Reports on chemical constituents of this broad spectrum species show that E. schimperi leaves possess embelin and rapanone (Midiwo \& Manguro, 1993), schimperinone (Machocho et al., 2003), oleanane-type triterpenes (Manguro et al., 2006), and flavonol glycosides (Manguro et al., 2004). Embelin has been reported for its antibacterial properties against $S$. aureus, $S$. pyogenes, and $P$. aeruginosa (Chitra et al., 2003). A wide spectrum of biological and pharmacological property of embelin has also been described by Machocho et al. (2003). Hence, the broadest spectrum action (against $67 \%$ of the microbes in the present study) and the strong antimicrobial activity (MIC $64 \mu \mathrm{g} / \mathrm{ml}$ ) shown by both leaf and twig extracts of E. schimperi against $B$. cereus, L. monocytogenes and $S$. pyogenes could be attributed to the existence of such active chemicals with pharmacological properties.

Runyoro et al. (2010) applied an agar-dilution technique and reported antimicrobial role of extracts from $O$. lamiifolium against $S$. aureus and $S$. epidermidis, which corresponds to the present results. In addition, the investigated strong growth inhibitory activity of extracts from $O$. lamiifolium and $R$. steudneri was also found to support recorded ethnobotanical uses of the species to treat common bacterial diseases, such as diarrhoea, in the District. Previous studies have described anti-inflammatory, anti-pyretic, and analgesic properties of aqueous and ethanol extracts of leaves from O. lamiifolium (Makonnen et al., 2003a,b; Mequanint et al., 2011). Growth inhibition of $S$. aureus and $P$. aeruguinosa by methanolic extracts of $R$. steudneri has also been reported by Kamoga (2010), which also matches the current findings.

The presence of chemical compounds including bornyl acetate, $p$-cymene, camphene, $\alpha$-pinene, and sabinene was also reported from the essential oil analysis of $O$. lamiifolium (Runyoro et al., 2010; Tchoumbougnang et al., 2006). A literature search for relevant information on antimicrobial activities of chemicals from this plant shows the antimicrobial role of sabinene (Oji \& Shafaghat, 2012; Tchoumbougnang et al., 2006) and bornyl acetate (Runyoro et al., 2010). Therefore, the observed broad spectrum activity from extracts of $O$. lamiifolium could relate to these active components.

Although our results demonstrate significant antimicrobial effects of extracts from $R$. steudneri, inhibiting growth of $67 \%$ of microbes tested in this study, no report was found on its chemical constituents. Hence, this new observation calls for an in-depth investigation on $R$. steudneri to isolate and characterise its antimicrobial active components.

Antimicrobial action of extracts from J. abyssinicum, $B$. abyssinica, $R$. nepalensis, and $V$. amygdalina against three or more strains also relates to their traditional use reports (Getahun, 1976; Goji et al., 2006; Lulekal et al., 2008; Mesfin et al., 2009). A report by Goji et al. (2006) described the antibacterial role of leaf extracts of J. abysinicum against $S$. aureus, $P$. aeruginosa, and $S$. pyogenes through an agar well-diffusion method. The results of the present work are in agreement with the reported antimicrobial activity against $S$. pyogenes but not with that of $S$. aureus and $P$. aeruginosa. The discrepancy may be attributed to differences in methods followed for activity testing. A difference in geographical location, season, and developmental stages of samples collected could also be mentioned as factors for differences in outputs of activity tests (Runyoro et al., 2010). A report by Gallo et al. (2006) on chemical constituents of root bark of $J$. abyssinicum stated the presence of esters of a cyclopentanoid monoterpene but no information on their antimicrobial effect was available.

Geyid et al. (2005) used the agar-dilution method and reported antimicrobial role of root and stem bark extracts of B. abyssinica against $S$. aureus at concentrations between 500 and $2000 \mu \mathrm{g} / \mathrm{ml}$, but in the present work, we found no activity for this species for the range we tested for. The antimicrobial effect of $R$. nepalensis on $S$. aureus reported by Hussain et al. (2010) was also found to be in agreement with the results of this work but their report against $E$. coli differs from our results. The observed discrepancy may be attributed to differences in solvents used for extraction and methods followed for activity testing besides aforementioned factors that could bring differences in output of activity tests.

Stem and leaf extracts of $V$. amygdalina have also been reported for antimicrobial role against Klebisella spp. (Uzoigwe \& Agwa, 2011). The same authors have also shown that $E$. coli is not susceptible to extracts of $V$. amygdalina, which matches our own finding. Ijeh \& Ejike (2011) reviewed current perspectives on medicinal potentials of $V$. amygdalina. Chemical constituents of $V$. amygdalina include flavonoids, steroidal alcohols, and sesquiterpene lactones have also been reported as chemically active by Luo et al. (2010). The latter may be responsible for the relatively broad spectrum of actions of this species observed in the present work.

Our investigation has shown that Gram-positive bacteria are more susceptible to tested medicinal plant extracts than Gram-negative ones. This might relate to differences in cell wall morphology of the two groups of bacteria. Hodges (2002) explained that Gram-negative bacteria have an outer phospholipid membrane composed of lipo-polysaccharide constituents that make their cell wall impermeable to antimicrobial chemicals, whereas Gram-positive groups possess cell walls composed of a peptidoglycogen layer that is an inefficient permeability barrier. Although there are such barriers in Gram-negative bacteria, extracts of $R$. steudneri were found to be the only ones to be active and effective against two of the Gram-negative bacteria, i.e., P. aeruguinosa and S. enteritidis. Moreover, among the Gram-negative groups, B. fragilis and E. coli were found susceptible to none of the extracts and this could also partly be attributed to cell wall impermeability. Multi-drug resistance of Gram-negative bacteria has also been reported by Sader et al. (2002). Earlier 
reports also confirmed that Gram-negative bacteria are less susceptible to diverse medicinal plant extracts than Grampositive groups (Kloucek et al., 2005; Tadeg et al., 2005) hence supporting the present result.

\section{Conclusions}

In conclusion, herbal extracts from traditional medicinal plants have been attracting scientific interests due to their potential as sources of chemicals against microbes. We were able to show that $74 \%$ of the medicinal plant extracts tested exhibited antimicrobial effect against one or more of the 12 different microbial strains. We found E. schimperi, $O$. lamiifolium, and $R$. steudneri to be the most promising plants for a potential discovery of lead compounds against microbes. The antimicrobial activity of extracts from $J$. abyssinicum, B. abyssinica, $R$. nepalensis, and $V$. amygdalina are also promising and calls for further investigation. Among the most promising plants for antimicrobial properties, E. schimperi and $O$. lamiifolium were found with few reports on chemical constituents whereas no report was found for $R$. steudneri. Hence, further studies on isolation and characterisation of chemicals from these species that are responsible for the observed activities against microbes are highly recommended. More scientific studies on medicinal plants with traditional use reports will also bring more useful results that contribute significant role in the fight against pathogens.

\section{Acknowledgements}

We are indebted to the inhabitants of Ankober District, particularly the traditional medical practitioners who unreservedly shared with us their knowledge on medicinal plants. Staff members of The National Herbarium (Ethiopia) are also acknowledged for their cooperation at all aspects of the herbarium work. Dr. Henok Lulekal from WDAO, North Shewa, and Sr. Tsehay Aytenew, Hayat Hospital AA, both from Ethiopia, are acknowledged in translating local names of diseases into their English equivalents based on the descriptions of symptoms. Staff members of digital libraries of AAU, UGent, and UNECA are also acknowledged for providing references for this work. We thank Mr Ashenafi Mihrete, Mr Abebe Shewamene, Mr Getu Shewamene, and Mr. Dawit Tewabe for their field assistantship. We also extend our gratitude to administrative officials of Ankober Woreda Development Association, Ankober District, Debre Berhan University, and Increasing People Opportunity (IPO) office in Ethiopia for their support in facilitating the study.

\section{Declaration of interest}

The authors report no declarations of interest. We are grateful to the Research and Graduate Programs Office, Addis Ababa University (AAU) for funding the cost of field expenses. We are also indebted to The Bijzonder Onderzoeksfonds (BOF) project and the Committee for Scientific Research under the Faculty of Bioscience Engineering, Ghent University (UGent) for the travel grant supplied to the laboratory work.

\section{References}

Abebe D. (1986). Traditional medicine in Ethiopia: The attempts being made to promote it for effective and better utilization. SINET: Ethiop J Sci 9:61-9.

Awas T, Demissew S. (2008). Ethnobotanical study of medicinal plants in Kafficho People, Southwestern Ethiopia. In: Ege S, Aspen $\mathrm{H}$, Teferra B, Bekele S. eds. Proceedings of the 16th International Conference of Ethiopian Studies, Trondheim: Norway, 711-26.

-Awino OS, Kiprono, PC, Keronei KP, et al. (2008). Antimicrobial activity of 2,5-dihydroxy-3-methyl-1,4-benzoquinone from Embelia schimperi. J Biosci 63:47-50.

Belay G, Tariku Y, Kebede T, et al. (2011). Ethnopharmacological investigations of essential oils isolated from five Ethiopian medicinal plants against eleven pathogenic bacterial strains. Phytopharmacology $1: 133-43$.

- Bøgh HO, Andreassen J, Lemmich J. (1996). Anthelmintic usage of extracts of Embelia schimperi from Tanzania. J Ethnopharmacol 50: $35-42$.

Bussmann RW, Swartzinsky P, Worede A, Evangelista P. (2011). Plant use in Odo-Bulu and Demaro, Bale region, Ethiopia. J Ethnobiol Ethnomed 7:28.

- Buwa LV, van Staden J. (2006). Antibacterial and antifungal activity of traditional medicinal plants used against venereal diseases in South Africa. J Ethnopharmacol 103:139-42.

Cecchi DA. (1886). Da Zeila Alle Frontiere Dela Caffa, Vol. I. Roma, Italy: Della Societa Geografica Italiana. Ermanno Loescher \& Co.

-Chitra M, Shyamala DCS, Sukmar E. (2003). Antibacterial activity of embelin. Fitoterapia 74:401-3.

Cos P, Vlietinck AJ, Vanden Berghe D, Maes L. (2006). Anti-infective potential of natural products: How to develop a stronger in vitro 'proof-of-concept'. J Ethnopharmacol 106:290-2.

Demissew S, Dagne E. (2001). Basic and applied research in medicinal plants. In: Zewdu M, Demissie A, eds. Proceedings of the National Workshop on Biodiversity Conservation and Sustainable Use of Medicinal Plants in Ethiopia. Addis Ababa, Ethiopia: IBCR.

-Desta B. (1993). Ethiopian traditional herbal drugs. Part II: Antimicrobial activity of 63 medicinal plants. J Ethnopharmacol 39: 129-39.

Edwards S, Tadesse M, Demissew S, Hedberg I, eds. (2000) Flora of Ethiopia and Eritrea. Magnoliaceae to Flacourtiaceae, Vol. 2:1. Addis Ababa, Ethiopia and Uppsala, Sweden: The National Herbarium and Department of Systematic Botany.

-Eguale T, Tilahun G, Debella A, et al. (2007). In vitro and in vivo anthelmintic activity of crude extracts of Coriandrum sativum against Haemonchus contortus. J Ethnopharmacol 110:428-33.

- Flatie T, Teferi T, Asres K, Gebre-Mariam T. (2009). Ethnomedical survey of Berta ethnic group Assosa Zone, Benishangul-Gumuz regional state, mid-west Ethiopia. J Ethnobiol Ethnomed 5:14.

-Gallo FR, Palazzino G, Federici E, et al. (2006). Oligomeric secoiridoid glucosides from Jasminum abyssinicum. Phytochemistry 67:504-10.

Ganora R. (1929). Flora medica Etiopica. Archivio Italiano di Scienze Mediche Tropicali e diParassitologia 10:97-120.

Gebre-Mariam T, Neubert R, Schmidt PC, et al. (2006). Antiviral activities of some Ethiopian medicinal plants used for the treatment of dermatological disorders. J Ethnopharmacol 104:182-7.

Gedif T, Hahn H. (2003). The use of medicinal plants in self-care in rural central Ethiopia. J Ethnopharmacol 87:155-61.

Getahun A. (1976). Some Common Medicinal and Poisonous Plants Used in Ethiopian Folk Medicine. Addis Ababa, Ethiopia: Addis Ababa University Press.

$\checkmark$ Geyid A, Abebe D, Debella A, et al. (2005). Screening of some medicinal plants of Ethiopia for their anti-microbial properties and chemical profiles. J Ethnopharmacol 97:421-7.

Giday M, Asfaw Z, Woldu Z. (2009). Medicinal plants of the Meinit ethnic group of Ethiopia: An ethnobotanical study. J Ethnopharmacol 124:413-21.

- Giday M, Asfaw Z, Woldu Z. (2010). Ethnomedicinal study of plants used by Sheko ethnic group of Ethiopia. J Ethnopharmacol 132: $75-85$.

- Giday M, Teklehaymanot T, Animut A, Mekonnen Y. (2007). Medicinal plants of the Shinasha, Agew-awi and Amhara peoples in northwest Ethiopia. J Ethnopharmacol 110:516-25. 
Goji M, Gebre-Mariam T, Asres K, et al. (2006). Screening of antimicrobial activities of some plants used traditionally in Ethiopia for the treatment of skin disorders. Ethiop Pharmaceut J 24:130-5.

Griaule M. (1928). Mythes, croyances et coutumes du Bégamder (Abyssinie). Paris, France: Sonderdruck.

Hedberg I, Edwards S, eds. (1989). Flora of Ethiopia and Eritrea, Pittospoaceae to Araliaceae, Vol. 3. Addis Ababa, Ethiopia and Uppsala Sweden: The National Herbarium and Department of Systematic Botany.

Hedberg I, Edwards S, Nemomissa S., eds. (2003). Flora of Ethiopia and Eritrea. Apiaceae to Dipsacaceae, Vol. 4:1. Addis Ababa, Ethiopia and Uppsala, Sweden: The National Herbarium and Department of Systematic Botany.

Hodges N. (2002). Pharmaceutical applications of microbiological techniques. In: Aulton ME, ed. Pharmaceutics: The Science of Dosage Form Design, 2nd ed. London: Harcourt Publishers Limited, 62-70.

Hussain S, Jamil M, Ullah F, et al. (2010). Antimicrobial and antioxidant activities of the plant Heliotropium strigosum. Afr J Biotechnol 9: 7738-43.

Ijeh II, Ejike CEC. (2011). Current perspectives on the medicinal potentials of Vernonia amygdalina Del. J Med Plants Res 5:1051-61.

Jorgensen JH, Turnidge JD, Washington JA. (1999). Antibacterial susceptibility tests: Dilution and disk diffusion methods. In: Murray PR, Baron EJ, Pfaller MA, Tenover FC, Yolken RH, eds. Manual of Clinical Microbiology, 7th ed. Washington: ASM Press, 1526-43.

Kamoga D. (2010). Some pharmacological activities of selected medicinal plant species used for treating cattle diseases in Kabira sub-county, Rakai District [MSc. thesis submitted to the school of graduate studies Makerere University, Uganda] (unpublished).

Kibebew F. (2001). The status and availability of oral and written knowledge on traditional healthcare on traditional health care in Ethiopia. In: Zewdu M, Demissie A, eds. Proceedings of the National Workshop on Biodiversity Conservation and Sustainable Use of Medicinal Plants in Ethiopia. Addis Ababa, Ethiopia: IBCR, 107-19.

Kloucek P, Polesny Z, Svobodova B, et al. (2005). Antibacterial screening of some Peruvian medicinal plants used in Calleria District. $J$ Ethnopharmacol 99:309-12.

Kokwaro JO. (1976). Medicinal Plants of East Africa. Nairobi: East African Literature Bureau.

Lulekal E, Kelbessa E, Bekele T, Yineger H. (2008). An ethnobotanical study of medicinal plants in Mana Angetu District Southeastern Ethiopia. J Ethnobiol Ethnomed 4:10.

Luo X, Jiang Y, Fronczek FR, et al. (2010). Isolation and structure determination of a sesquiterpene lactone (vernodalinol) from Vernonia amygdalina extracts. Pharm Biol 49:464-70.

- Machocho AK, Kiprono PC, Grinberg S, Bittner S. (2003). Pentacyclic triterpenoids from Embelia schimperi. Phytochemistry 62:573-7.

-Makonnen E, Debella A, Abebe D, Teka T. (2003a). Analgesic properties of some Ethiopian medicinal plants in different models of nociception in mice. Phytother Res 17:1108-12.

Makonnen E, Debella, A, Zerihun L, et al. (2003b). Anti-pyretic properties of the aqueous and ethanol extracts of the leaves of Ocimum suave and Ocimum lamiifolium in mice. J Ethnopharmacol 88:85-91.

-Manguro LOA, Okwiri, SO, Lemmen P. (2006). Oleanene-type triterpenes of Embelia schimperi leaves. Phytochemistry 67:2641-50.

- Manguro LOA, Ugi I, Lemmen P. (2004). Further flavonol glycosides of Embelia schimperi leaves. B Chem Soc Ethiopia 18:51-7.

-Mequanint W, Makonnen E, Urga K. (2011). In vivo anti-inflammatory activities of leaf extracts of Ocimum lamiifolium in mice model. $J$ Ethnopharmacol 134:32-6.

Mérab P. (1912). Médecins et médecine en Ethiopie. Paris, France: Vigot frères.

-Mesfin F, Demissew S, Teklehaymanot T. (2009). An ethnobotanical study of medicinal plants in Wonago Woreda, SNNPR, Ethiopia. $J$ Ethnobiol Ethnomed 5:28.

- Midiwo JO, Manguro LOA. (1993). Polynuclear acetogenic pigments in the fruits of the Myrsinaceae. BioChemiPhysics 2:115-18.

-Oji KA, Shafaghat A. (2012). Constituents and antimicrobial activity of the essential oils from flower, leaf and stem of Helichrysum armenium. Nat Prod Commun 7:671-4.

Pascaline J, Charles M, Lukhoba C, George O. (2011). Phytochemical constituents of some medicinal plants used by the Nandis of South Nandi District, Kenya. J Anim Plant Sci 9:1201-10.
Pearce N. (1831) The Life and Adventures of Nathaniel Pearce, Vol. I. London, New Burlington Street: Henry Colburn and Richard Bentley.

Runyoro D, Ngassapa O, Vagionas K, et al. (2010). Chemical composition and antimicrobial activity of the essential oils of four Ocimum species growing in Tanzania. Food Chemistry 119:311-16.

- Sader HS, Jones RN, Silva JB. (2002). Skin and soft tissue infections in Latin American Medical Centers: Four-year assessment of the pathogen frequency and antimicrobial susceptibility patterns. Diagn Micr Infect Dis 44:281-8.

- Savithramma N, Ankanna S, Linga RM, Saradvathi J. (2012). Studies on antimicrobial efficacy of medicinal tuberous shrub Talinum cuneifolium. J Environ Biol 33:775-80.

Sori T, Bekana M, Adugna G, Kelbessa E. (2004). Medicinal plants in the ethnoveterinary practices of Borana Pastoralists, Southern Ethiopia. Int J Appl Res Vet M 2:220-25.

Strelcyn S. (1968). Médecine et plantes d'Ethiopie. I. Les Traités médicaux Ethiopiens, Warszawa: Panstwowe Wydawnictwo Naukowe.

Strelcyn S. (1973). Médecine et plantes d'Ethiopie.II. Enquête sur les noms et l' emploi des plantes en Ethiopie. Napoli: Istituto Universitario Orientale.

- Tadeg H, Mohammed E, Asres K, Gebre-Mariam T. (2005). Antimicrobial activities of some selected traditional Ethiopian medicinal plants used in the treatment of skin disorders. J Ethnopharmacol 100:168-75.

Tadesse D, Eguale T, Giday M, Mussa A. (2009). Ovicidal and larvicidal activity of crude extracts of Maesa lanceolata and Plectranthus punctatus against Haemonchus contortus. J Ethnopharmacol 122: $240-4$.

- Taye B, Giday M, Animut A, Seid J. (2011). Antibacterial activities of selected medicinal plants in traditional treatment of human wounds in Ethiopia. Asian Pac J Trop Biomed 2011:370-5.

- Tchoumbougnang F, Amvam Zollo PH, Avlessi F, et al. (2006). Variability in the chemical compositions of the essential oils of five Ocimum species from tropical African area. J Essent Oil Res 18: 194-9.

Teklehaymanot T, Giday M. (2007). Ethnobotanical study of medicinal plants used by people in Zegie peninsula, northwestern Ethiopia. J Ethnobiol Ethnomed 3:12.

Teklehaymanot T. (2009). Ethnobotanical study of knowledge and medicinal plants use by the people in Dek Island in Ethiopia. J Ethnopharmacol 124:69-78.

Tekwu EM, Pieme AC, Beng VP. (2012). Investigations of antimicrobial activity of some Cameroonian medicinal plant extracts against bacteria and yeast with gastrointestinal relevance. J Ethnopharmacol 142:265-73.

Theuretzbacher U. (2012). Accelerating resistance, inadequate antibacterial drug pipelines and international responses. Int $J$ Antimicrob Agents 39:295-9.

-Uzoigwe CI, Agwa OK. (2011). Antimicrobial activity of Vernonia amygdalina on selected urinary tract pathogens. Afr J Microbiol Res 5: 1467-72.

-Verpoorte R, Choi YH, Kim HK. (2005). Ethnopharmacology and systems biology: A perfect holistic match. J Ethnopharmacol 100: 53-6.

Wabe NT, Mohammed MA, Raju NJ. (2011). An ethnobotanical survey of medicinal plants used in the Southeast Ethiopia used in traditional medicine. Spatula DD 1:153-8.

WHO. (2008). Traditional Medicine. Fact Sheet, No. 134, 2008. Available at http://www.who.int/mediacentre/factsheets/fs134/en/ [last accessed 17 Sep 2012].

-Wondimu T, Asfaw Z, Kelbessa E. (2007). Ethnobotanical study of medicinal plants around 'Dheeraa' town, Arsi Zone, Ethiopia. $J$ Ethnopharmacol 112:152-61.

- Yineger H, Kelbessa E, Bekele T, Lulekal E. (2007). Ethnoveterinary medicinal plants at Bale Mountains National Park, Ethiopia. J Ethnopharmacol 112:55-70.

- Yineger H, Kelbessa E, Bekele T, Lulekal E. (2008). Plants used in traditional management of human ailments at Bale Mountains National Park, Southeastern Ethiopia. J Med Plants Res 2: 132-53.

- Yonathan, M, Asres K, Assefa A, Bucar F. (2006). In vivo antiinflammatory and anti-nociceptive activities of Chelianthes farinosa. J Ethnopharmacol 108:462-70. 